RADOVI

Zavoda za znanstveni rad HAZU Varaždin

ANA ŠKRILJEVEČKI

Varaždin

askriljevecki@gmail.com
UDK 929.52Ožegović(497.523Bela)

Prethodno priopćenje

Preliminary Communication
Primljeno: 24. 10. 2018.

Prihvaćeno: 14. 11. 2018.

DOI: https://dx.doi.org/10.21857/y54jofp18m

\title{
OBITELJ OŽEGOVIĆ U BELI
}

Obitelj Ožegović posjedovala je dobro Bela više od sto godina i svojim ga je gospodarenjem učinila izuzetno naprednim vlastelinstvom. U radu su kronološkim redom predstavljeni članovi obitelji Ožegović koji su živjeli $i$ djelovali u Beli. Prikazane su njihove životne prilike $i$ društveni rad te njihov odraz na upravljanje belskim posjedom i njegov razvoj. Naposljetku su opisani razlozi koji su doveli do odlaska obitelji Ožegović iz Bele $i$ do njezinog propadanja.

\section{OBITELJ OŽEGOVIĆ}

Obitelj Ožegović pripada potkalničkom sitnom plemstvu. Plemićki je status stekla sredinom 13. stoljeća. ${ }^{1}$ Godine 1858. senjsko-modruški biskup Mirko Ožegović dobiva barunat koji ima pravo prenijeti na nećaka Metela Ožegovića i njegovog sina. ${ }^{2}$ Postoji više grana obitelji koje su posjedovale vlastelinstva širom Hrvatske, a često su boravile na svojim imanjima u inozemstvu. Svojim su radom dali važan doprinos političkom i kulturnom životu Hrvatske u 19. stoljeću. Metel Ožegović uz svojega oca Stjepana Ožegovića i strica Mirka Ožegovića spada u najznačajnije članove obitelji. Uz pridjevak Barlabaševački / Barlabaševečki, koji su Ožegovići stavili u svoju titulu naglašavajući podrijetlo iz mjesta Barlabaševac / Barlabaševec, koje se danas nalazi u Koprivničko-križevačkoj županiji, dio je

1 Ozren BLAGEC, „Bela IV. i kalničko plemstvo“, Cris: časopis Povijesnog društva Križevci, XII/1, Povijesno društvo Križevci, Križevci, 2010., 237 - 238.

2 Ivan BOJNIČIĆ, Der Adel von Kroatien und Slavonien, pretisak prvog izdanja iz 1899. godine, Golden Marketing, Zagreb, 1995., 136 - 137; Agneza SZABO, „Metel Ožegović u političkom i kulturno-prosvjetnom životu Hrvatske“, Cris: časopis Povijesnog društva Križevci, XIV/1, Povijesno društvo Križevci, Križevci, 2012., 196. 
njihovog imena bio i pridjevak Belski prema njihovom posjedu Bela u Varaždinskoj županiji.

\section{BELA PRIJE DOLASKA OBITELJI OŽEGOVIĆ}

Naselje Bela smješteno je uz rijeku Bednju na sjeveroistočnim padinama Ivanščice. Administrativno pripada Gradu Novom Marofu od kojeg je udaljeno trinaest kilometara. ${ }^{3}$ Naselje je dobilo ime po istoimenom burgu na padinama Ivanščice. Naziv se burga najvjerojatnije odnosio na bjelinu njegovih zidina ili pak, kao što je slučaj u slavenskim zemljama, na hidronim Bela i boju vode. ${ }^{4}$ Naime, podno utvrde protječe potok Belščina (Belščak). Najstariji poznati gospodari burga bili su ivanovci, viteški red svetoga Ivana Jeruzalemskog, koji su posjedovali zemlje oko Ivanščice već od kraja 12. stoljeća. Utvrđeni grad Bela bio je njihovo sjedište. ${ }^{5}$ Bela je promijenila mnogobrojne vlasnike, a naposljetku je bila napuštena zbog izgradnje novih objekata u njezinom podnožju. Otuda potječe naziv Pusta Bela za zapušteni burg. Podno utvrde Bela obitelj Petheö de Gerse gradi kaštel Belu I (Gornja Bela) u 17. stoljeću. ${ }^{6}$ Bela I jednokatna je građevina pravokutnog tlocrta koja na zapadnom pročelju ima trokatnu kulu te za kaštel tipično naglasak stavlja na obrambenu funkciju u koju ulazi obrambeni jarak, pomični most i obrambeni zid. Male okrugle obrambene kule na uglovima obrambenog zida koji okružuje kaštel izgrađene su najvjerojatnije u 18. stoljeću. ${ }^{7}$ Arhitektura u službi obrane dolaskom mirnih vremena gubi svoju svrhu te kaštel u skladu s potrebama vlasnika postupno biva preuređivan $u$ dvorac.

Ana BEČEHELI et al., Novi Marof nekad $i$ danas, Grad Novi Marof, Turistička zajednica Grada Novog Marofa, Novi Marof, 2015., 165.

4 Juraj BELAJ, „Bela - ivanovački burg na Ivanščici“, Prilozi Instituta za arheologiju u Zagrebu, vol. 25, br. 1, Institut za arheologiju, Zagreb, 2009., 157 - 159.

5 Marijan KRAŠ, Ivanec: prilozi povijesti Ivanca do 1940. godine, Zlati ajngel, Varaždin, 1996., 22; Lelja DOBRONIĆ, Templari i ivanovci u Hrvatskoj, Dom i svijet, Zagreb, 2002., 127, 137, 140.

6 Mladen OBAD ŠĆITAROCI, Dvorci i perivoji Hrvatskoga zagorja, Školska knjiga, Zagreb, 1993., 40.

7 Milan KRUHEK, Krajiške utvrde i obrana hrvatskog kraljevstva tijekom 16. stoljeća, Institut za suvremenu povijest, Zagreb, 1995., 30; M. OBAD ŠĆITAROCI, n. dj., 40. 


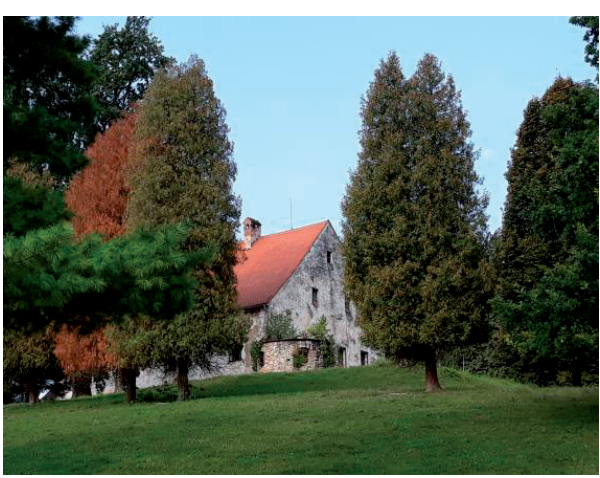

Slika 1. Dvorac Bela I s perivojem (FOTO: Ana Škriljevečki).

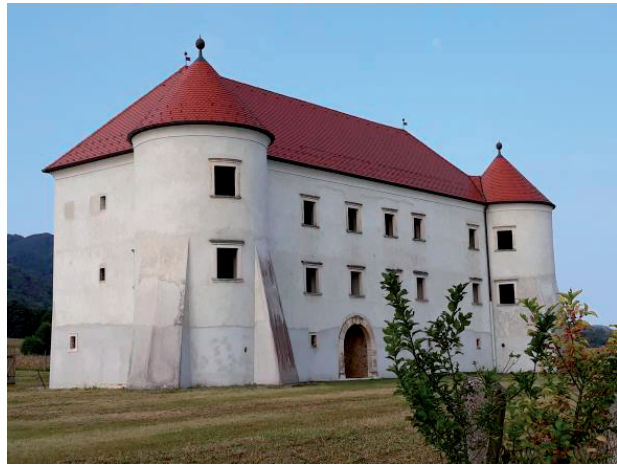

Slika 2. Dvorac Bela II (FOTO: Ana Škriljevečki).

Drugi je objekt na istome posjedu izgrađen u blizini Bele I, ali na nižoj nadmorskoj visini, i nazvan Bela II (Donja Bela). Prema Konzervatorskoj studiji iz 2004. godine Žmegač datira Belu II u sredinu 17. stoljeća ${ }^{8}$ kada je posjed još uvijek bio u vlasništvu obitelji Petheö de Gerse. ${ }^{9}$ Bela II rezidencijalna je građevina, jednokrilni dvorac s dvije kule. Pročelje je na sjevernoj strani dvorca, okrenuto prema rijeci Bednji, a začelje na južnoj strani gleda prema Ivanščici. ${ }^{10}$ Bela II građena je u stilu baroka te je prepoznatljiva po arkadnim trijemovima na začelju i ugaonim kulama na pročelju koje imaju dekorativnu funkciju. ${ }^{11}$ Oba dvorca te kultivirani krajolik na njihovom području ulazi u zaštićena kulturna dobra Republike Hrvatske. ${ }^{12}$ Budući da se nalaze podno utvrde koja je prva nosila naziv Bela, za oba se dvorca u narodu ustalio naziv Podbela koji se može čuti i danas. Njihovi su se vlasnici nazivali belskim i/ili podbelskim vlastelinima.

8 Andrej ŽMEGAČ, „Prilog poznavanju dvorca Bela II.“, Kaj: časopis za književnost, umjetnost i kulturu, god. 40, br. 1 -2, Kajkavsko spravišče - društvo za širenje i unapređivanje znanosti i umjetnosti, Zagreb, 2007., 69.

9 Gjuro SZABO, Kroz Hrvatsko Zagorje, Izdanje knjižare Vasić (Vasić i Horvat), Zagreb, 1939., 78

10 A. ŽMEGAČ, n. dj., 65, 69.

11 Anđela HORVAT, Radmila MATEJČIĆ, Kruno PRIJATELJ, Barok u Hrvatskoj, Sveučilišna naklada Liber - Odjel za povijest umjetnosti Centra za povijesne znanosti - Društvo povjesničara umjetnosti Hrvatske - Grafički zavod Hrvatske - Kršćanska sadašnjost, Zagreb, 1982., 79, 97, 307; A. ŽMEGAČ, n. dj., 69.

12 Ministarstvo kulture Republike Hrvatske, Registar kulturnih dobara Republike Hrvatske, URL: https://www.min-kulture.hr/default.aspx?id=6212 datum pristupa: 22. kolovoza 2018. 


\section{STJEPAN OŽEGOVIĆ}

Iako se $\mathrm{u}$ literaturi redovito navodi ${ }^{13}$ da je od obitelji Ožegović prvi vlasnik belskoga posjeda bio Metel, to je imanje prethodno bilo u vlasništvu njegovog oca Stjepana Ožegovića (Vinarec, 8. kolovoza 1770. - 6. prosinca 1837.). ${ }^{14}$ Najstariji dokument koji spominje Stjepana Ožegovića kao vlasnika dijela belskoga posjeda potječe iz 1822. godine. Riječ je o Priznanici Ane Culifaj rođene Marković, sestre Stjepanove supruge Jozefine Marković, kojom potvrđuje isplatu iznosa za kupnju šume iz belskoga imanja. ${ }^{15} \mathrm{U}$ tekstu navodi da će daljnje transakcije u vezi belskoga posjeda Stjepan Ožegović vršiti s njezinim zetom Jurom Barabašem koji je držao njezin dio imanja. Dakle, belski posjed u to vrijeme nije bio cjelovit. Takvo je stanje posljedica sudske parnice koju je obitelj Petheö de Gerse pokrenula protiv grofova Erdödy za vlasništvo nad Belom. Nakon presude 1817. godine obitelji Josipović, Lovinčić i Barabaš naslijedile su Belu od grofova Petheö de Gerse. ${ }^{16}$ Stoga možemo zaključiti da su od navedenih vlasnika Stjepan Ožegović, a kasnije njegov sin Metel, postupno kupovali dijelove imanja. Godine

13 Belošević navodi Metela Ožegovića kao prvog člana obitelji Ožegović koji je posjedovao vlastelinstvo Bela te 1858. kao najraniju godinu kupnje dijela imanja. Prema Beloševiću, te je godine Metel Ožegović kupio dijelove belskoga posjeda od Josipovića i Lovinčića (Stjepan BELOŠEVIĆ, Županija varaždinska i slob. i kralj. grad Varaždin / napisao Stjepan Belošević, Gornjo-Stubički veliki župan Županije varaždinske i slob. kralj. grada Varaždina, Vlastita naklada, Zagreb, 1926., 115). Na Beloševića se redovito poziva novija literatura uključujući: M. OBAD ŠĆITAROCI, n. dj., 40; Tomislav ĐURIĆ, Dragutin FELETAR, Stari gradovi, dvorci i crkve sjeverozapadne Hrvatske, treće dopunjeno i prerađeno izdanje, Ogranak Matice Hrvatske, Koprivnica, i autori, Koprivnica, 1991., 150, autori koji posvećuju najviše prostora izgledu vlastelinstva Bela i životu na imanju u vrijeme Ožegovića.

14 Gradski muzej Varaždin (dalje GMV), Galerija starih i novih majstora, inv. br. GMV GS $790=$ GMV KPO 1989, Portret protonotora Stjepana plemenitog Ožegovića, Michael Stroy, 1837. godina s natpisom: Magn: et Spect: D. Stephanus Osegovich de Barlabassevecz Cons. R. Equ: Aurat: et Regn: Dalm. Croat: ac Slavon Magr Protho-Notarius natus 8 Aug: 1770 obiit die 6. Decemb: $183768^{\circ}$ Etatis anno. Na hrvatskome jeziku natpis glasi: Velemožni i poštovani gospodin Stjepan Ožegović od Barlabaševca, kraljevski savjetnik, vitez Reda zlatne ostruge, prabilježnik Kraljevina Dalmacije, Hrvatske i Slavonije, rođen 8. kolovoza 1770., umro 6. prosinca 1837. u 68. godini. (Prijevod Karmen LEVANIĆ u: Krešimir Filić, Povijesni natpisi grada Varaždina, urednici Vladimir HUZJAN i Spomenka TEŽAK, biografske jedinice izradili Vladimir HUZJAN, Ana ŠKRILJEVEČKI i Spomenka TEŽAK, Hrvatska akademija znanosti i umjetnosti, Zavod za znanstveni rad u Varaždinu, Gradski muzej Varaždin, Zagreb - Varaždin, 2017., 155).

15 Državni arhiv u Varaždinu (dalje DAVŽ), Zbirni fond HR-DAVŽ-542 Razne obitelji XVI. - XX. stoljeća, kutija 2, broj 17, Ožegović Barlabaševečki (1822. - 1837.), Priznanica za tristo forinti primljenih po Ani udovi Culifaj rođenoj Marković od šurjaka Stjepana Ožegovića u ime isplate svojega dijela iz imanja Bela, Vadine, 2. siječnja 1822. godine.

16 S. BELOŠEVIĆ, n. dj., 101 - 103, 115; Julije JANKOVIĆ, Pabirci po povjesti županije Varaždinske / pribrao ih Julije Janković, Brzotiskom Stjepana Platzera, Varaždin, 1898., 51, 211; Gj. SZABO, Kroz Hrvatsko Zagorje, 78. 
1831. Stjepan Ožegović navodi se kao vlasnik dvorca Donja Bela. ${ }^{17} \mathrm{O}$ izgledu i veličini imanja Stjepana Ožegovića te njegovom upravljanju ima malo podataka. Zasigurno jedino znamo da je posjedovao mlađi dvorac i zemljište kojem su pripadali šuma i vinogradi. Vinograde je davao na uživanje seljacima ${ }^{18}$ pa možemo zaključiti da se već tada radilo o bogatom vlastelinstvu. Također je poznato da je Stjepan Ožegović bio jedan od pokrovitelja Župe svete Margarete Margečan (Župa se u to vrijeme nazivala Bela ili Pod Belom). ${ }^{19}$

Gotovo do kraja života Stjepan Ožegović boravio je u Beli, ${ }^{20}$ međutim tamo nije umro. Ne postoji zapis o njegovoj smrti u Matici umrlih Župe Margečan kojoj Bela pripada. U kapelici Majke Božje u Beli u neposrednoj blizini Ožegovićeva posjeda, koja je kasnije preuređena u obiteljsku grobnicu, nalazi se spomenik Stjepanu Ožegoviću. Zbog lošeg stanja, natpis je teško čitljiv. Razabire se da su Stjepanu nakon smrti spomenik podigli supruga Jozefina rođena Marković te sinovi Metel i Gustav. Iznad spomenika reljefni je grb obitelji Ožegović. ${ }^{21}$

17 Zbirni fond HR-DAVŽ-542 Razne obitelji XVI. - XX. stoljeća, kutija 2, broj 17, Ožegović Barlabaševečki (1822. - 1837.), Gorni list izdan Tomi Biškupu od Stjepana Ožegovića Barlabaševečkog za korištenje vinograda, Bela, 10. travnja 1831. godine. U dokumentu se spominje da je Bela dobro Stjepana Ožegovića (ad Bonum meum Bela) te se navodi Ožegovićev dvorac Donja Bela kao mjesto izdavanja dokumenta (in castello meo inferiore Bela).

18 Zbirni fond HR-DAVŽ-542 Razne obitelji XVI. - XX. stoljeća, kutija 2, broj 17, Ožegović Barlabaševečki (1822. - 1837.), Tri gorna lista izdana od Stjepana Ožegovića Barlabaševečkog za korištenje vinograda, Bela, 1831. godine.

19 Na južnom zidu svetišta u župnoj crkvi svete Margarete u Margečanu stoji spomenik Stjepanu Ožegoviću u obliku kamene ploče s latinskim natpisom, a ispod njega reljefni je grb obitelji Ožegović. Tekst natpisa bez prijevoda donosi Ivan Kukuljević Sakcinski u svojem djelu Natpisi sredovječni $i$ novovjeki... s time da je pogrešno pročitan datum smrti, 6. $7^{\text {bris }}$ (6. rujna) umjesto ispravnoga 6. $10^{\text {bris }}$ (6. prosinca). Ivan KUKULJEVIĆ-SAKCINSKI, Natpisi sredovječni i novovjeki na crkvah, javnih i privatnih zgradah itd. u Hrvatskoj i Slavoniji sabrao Ivan Kukuljević-Sakcinski, Knjižara Jugoslavenske akademije, Knjižara Dioničke tiskare, Zagreb, 1891., 6. Natpis na hrvatskome jeziku glasi: Velemožnomu i poštovanomu gospodinu Stjepanu Ožegoviću Barlabaševečkom, kraljevskom savjetniku, vitezu Reda zlatne ostruge, prabilježniku kraljevina Dalmacije, Hrvatske i Slavonije, supokrovitelju ove župe, dana 6. prosinca 1837. godine u dobi od 68 godina preranom smrću pozvanome u vječnost; onome koji nikada nije za sebe živio nego uvijek za domovinu i svoj (narod); zahvalni sin, nasljednik belskoga posjeda Metel Ožegović podigao je iz pobožnosti ovaj spomenik. (Prijevod autorice).

20 GMV, Povijesni odjel, inv. br. GMV 92254, Pismo podžupana Varaždinske županije Blaža Švagelja upućeno Stjepanu Ožegoviću u Belu, Varaždin, 15. lipnja 1836. godine.

21 Kapela Majke Božje u Beli, Spomenik Stjepanu Ožegoviću, o. 1837. godine. 


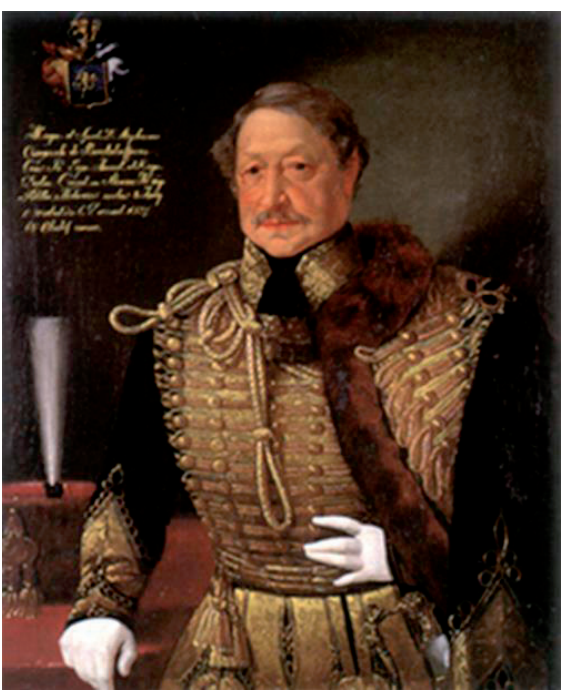

Slika 3. Portret Stjepana Ožegovića, 1837. godina, autor Michael Stroy (Gradski muzej Varaždin, Galerija starih i novih majstora, inv. br. KPO $1989=$ GS 790).

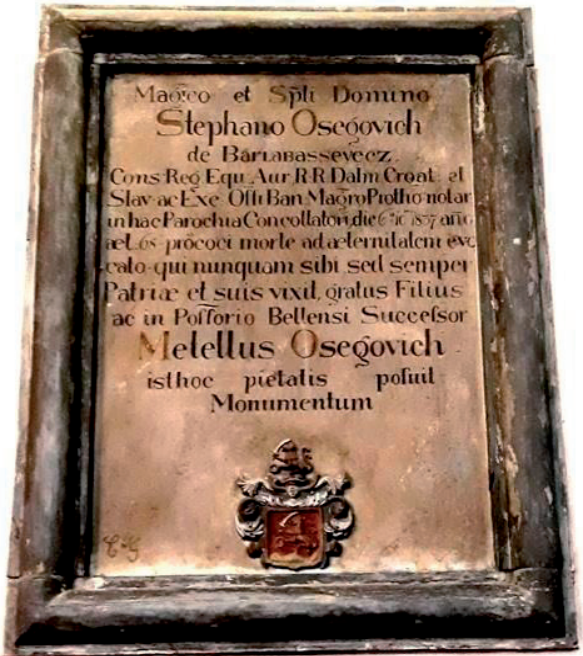

Slika 4. Spomen-ploča Stjepanu Ožegoviću koju mu je posvetio sin Metel Ožegović o. 1837. godine u župnoj crkvi sv. Margarete Margečan (Foto: Ana Škriljevečki).

\section{METEL OŽEGOVIĆ}

Nasljednik je Stjepana Ožegovića na belskome posjedu njegov sin Metel Ožegović (Zagreb, 4. svibnja 1814. - Hietzing, 9. veljače 1890.), što je dao istaknuti na spomen-ploči podignutoj svojemu ocu u župnoj crkve svete Margarete u Margečanu. ${ }^{22}$ Godinu dana nakon smrti Stjepana Ožegovića u Spomenici Župe Margečan Metel Ožegović spominje se kao zakoniti vlasnik dobra Bela, ${ }^{23}$ što se najvjerojatnije odnosilo na dio imanja s mlađim dvorcem koji je posjedovao njegov otac. Te je godine na svom posjedu osnovao pučku školu, ${ }^{24}$ jednu od prvih

22 Župna crkva svete Margarete Margečan, Spomen-ploča Stjepanu Ožegoviću koju mu je posvetio sin Metel Ožegović, o. 1837. godine, s natpisom: (...) in Possorio Bellensi successor Metellus Osegovich (...).

23 Župni ured Margečan (dalje ŽUM), Spomenica Župe svete Margarete Margečan, svezak I. (1724. - 2000.), zapis za 1838. godinu, str. 14: (...) Metellus Osegovich de Barlabassevecz (...) qua tamen Bonorum Bela legitimus possessor (...).

24 Osnovna škola Metel Ožegović Radovan (dalje OŠ Metel Ožegović), Spomenica Osnovne škole Metel Ožegović Radovan, knjiga I. (1883. - 1919.), Poviest škole, str. 29: (...) Metella Ožegovića 
modernih osnovnih škola u Varaždinskoj županiji (danas Osnovna škola Metel Ožegović Radovan). ${ }^{25}$ Godine 1841. u Spomenici Župe Margečan Metel Ožegović navodi se kao suposjednik na belskome posjedu, ${ }^{26}$ dakle u ovome slučaju riječ bi bila o čitavome belskome imanju koje još nije bilo u potpunosti u njegovom vlasništvu. Prema Beloševiću, Metel je postao vlasnik čitavog posjeda uključujući dva dvorca tek 1879. godine. ${ }^{27}$

Posjed Bela postaje Ožegovićevo najvažnije vlastelinstvo u koje znatno ulaže. Uredio je oba dvorca te perivoj uz stariji dvorac koji se 1860. godine prostirao na površini 5183 metara kvadratnih. Prilaz starijem dvorcu činila je aleja divljih kestenova duga pedesetak metara. Uz posjed Bela II $u$ to se vrijeme nalazio dekorativni cvjetni vrt površine 1062 metara kvadratnih smješten ispred sjevernoga pročelja te južno od dvorca uređen veći vrt. ${ }^{28}$ Pusta Bela također je bila u Ožegovićevu vlasništvu. Iz njezinih ruševina Metel je dao prenijeti željezna iskovana vrata i iskopano oružje u dvorac Belu I. ${ }^{29}$ Ujedno je dao očistiti okoliš oko utvrde, ukloniti hrašće i bukvik te se grad Biela već sa varaždinske ravnine prikazivao kao na visu labud bijeli. ${ }^{30}$

Vlastelinstvo Bela je pod Metelovom upravom oživjelo. Puno se činilo za razvoj gospodarstva. Uz oba su dvorca uređene gospodarske zgrade. Dio su imanja činile šumske, vinogradarske i poljoprivredne površine. Obitelj Ožegović bavila se poljodjelstvom, stočarstvom, vinogradarstvom i šumarstvom. Na imanju su radili seljaci s okolnih mjesta. Metel je brinuo o svojoj služinčadi u Beli. Bolesne je sluge dao smjestiti u bolnicu Društva "Varaždinska dobročinstva složnost". Godine 1860. dao je tisuću tristo forinti, uz mogućnost nadoplate iznosa narednih

(...) ide vječna slava da je u ovoj župi na svom imanju za siromašni neuki puk svoj, svoje tadanje kmetove osnovao veledušnimi darovi i pokloni svojimi na čelu ostaloj vlasteli ovu učionu. Ime je njegovo kano žarkog rodoljuba prvaka u borbi za narod naš i njegova prava zabilježeno zlatnimi pismeni u povjestnici narodnog pokreta, a zabilježeno mu je i u srdcih mnogoga siromašnoga seljaka kojemu je on budi sina dao izučiti, budi inače pomogao, neizbrisivo uvrieženo slavno ime njegovo.

25 Ankica KOŠĆAK, Katarina VUGREK, „Povijest školstva“, Škola Margečan: 1912. - 2012., uredile Ankica KOŠĆAK i Dubravka MIHINJAČ, TIVA Tiskara Varaždin - Osnovna škola Metel Ožegović Radovan, Varaždin, 2012., 14.

26 ŽUM, Spomenica Župe svete Margarete Margečan, svezak I. (1724. - 2000.), zapis za 1841. godinu, str. 14: (...) Metellus Osegovich de Barlabassevecz (...) conpossessor et concollator Bellensis (...).

27 S. BELOŠEVIĆ, n. dj., 115.

28 M. OBAD ŠĆITAROCI, n. dj., 40 - 41; T. ĐURIĆ, D. FELETAR, Stari gradovi, dvorci i crkve sjeverozapadne Hrvatske, 150; Drago BIŠĆAN, "Zapisi o Beli“, Hrvatski kajkavski kolendar 1995., Matica hrvatska Čakovec, Čakovec, 1994., 99.

29 Krešimir FILIĆ, „Stare gradine u Hrvatskom Zagorju“, Zagorski kolendar, Prosvjetno društvo hrvatskih Zagoraca „Matija Gubec“, Zagreb, 1958., 141.

30 Milan KUČENJAK, „Neki pabirci iz župe: Pod Bielom“, Naše pravice, 7. kolovoza 1913., br. 33, str. 2. 
godina, kako bi se osigurao jedan krevet za potrebe sluga s Bele. ${ }^{31}$ Metelova supruga Ivana također je dala donaciju bolnici Društva „Varaždinska dobročinstva složnost" $u$ iznosu od tisuću forinti te time osigurala da se u bolnici besplatno liječi jedan član njezine služinčadi s imanja Bela i Guščerovec tijekom sto dvadeset dana na godinu. ${ }^{32}$ Bela je bila obiteljsko imanje. Na njemu su uz Metelovu suprugu Ivanu, koja je brinula o kućnim poslovima u Metelovu odsustvu, ${ }^{33}$ boravila i njihova djeca, Ljudevit i Ida, koja se udala za baruna Alfreda Moscona, vlastelina u Pišecu u Štajerskoj. ${ }^{34}$ Metel Ožegović primarno je brinuo o Beli pa je Ljudevit Ožegović preuzeo upravljanje drugim obiteljskim imanjima, a na belskome je posjedu boravio povremeno. Na velikoj svečanosti na imanju Bela 1885. godine pred ocem je prisegnuo za carskog i kraljevskog komornika. ${ }^{35}$

Metel Ožegović, kao jedan od savjetnika za školstvo, zalagao se u varaždinskoj županijskoj skupštini za uvođenje trivijalnih i gradskih škola. ${ }^{36}$ Brinuo je o obrazovanju djece te o socijalnim prilikama u svome kraju. Davao je novčani pri$\log$ za rad učitelja pučke škole u Beli, podupro je izgradnju nove školske zgrade u naselju Radovan, redovito je pristupao završnom ispitu te se obvezao da će pokloniti dvadeset forinti srebra učenicima koji su se odlikovali znanjem i uzornim ponašanjem. ${ }^{37}$ Isticao se političkim ugledom kao veliki bilježnik Varaždinske županije (dužnost je obnašao od 1836. do 1845. godine) i iskrenim rodoljubljem te kao vođa preporoditelja u Varaždinu. ${ }^{38}$ Autor je Poziva u „Družtvo narodno“

31 GMV, Povijesni odjel, inv. br. GMV KPO 4836, Samuel MOSINGER, Kratka povjest družtva dobročinstva u Varaždinu, 1870., rukopis; Magdalena LONČARIĆ, Varaždinska dobrotvorna društva 1828. - 1945., katalog izložbe priređene povodom Dana grada Varaždina, Gradski muzej Varaždin, Varaždin, 2001., 4.

32 "Crtice iz prošlosti Dobrotvornoga društva u Varaždinu“, Slobodni gradjanin, 2. srpnja 1921., br. 26, str. 2; Magdalena LONČARIĆ, n. dj., 4.

33 Arhiv Hrvatske akademije znanosti i umjetnosti (dalje HAZU), Fond obitelji Ožegović, Acta Ožegovićiana, sign. OXXXVIII-23/o, Pismo Ivane Ožegović Metelu Ožegoviću, Bela, 18. kolovoza 1861. godine.

34 S. BELOŠEVIĆ, n. dj., 115.

35 Knjižnica Ministarstva kulture Republike Hrvatske, „,Domorodne misli baruna Metela Ožegovića“", Hrvatska prosvjeta: mjesečnik za književnost, umjetnost i prosvjetu, ožujak 1916., br. 3, str. 268 ; O. BLAGEC, n. dj., 146.

36 S. BELOŠEVIĆ, n. dj., 14; Eduard VARGOVIĆ, „Bibliografski izvori o Metelu Ožegoviću“, Radovi Zavoda za znanstveni rad Varaždin, broj 8 - 9, Hrvatska akademija znanosti i umjetnosti, Zavod za znanstveni rad Varaždin, Zagreb - Varaždin, 1996., 136.

37 Metel OŽEGOVIĆ, "Oglas“, Ilirske narodne novine, 15. prosinca 1838., br. 99, str. 396; OŠ Metel Ožegović, Spomenica Osnovne škole Metel Ožegović Radovan, knjiga I. (1883. - 1919.), Poviest škole, str. $30-31$.

38 Ernest FIŠER, „Skica za portret Metela Ožegovića“, Godišnjak Gradske knjižnice i čitaonice "Metel Ožegović“ Varaždin, god. 1, br. 1, Gradska knjižnica i čitaonica „Metel Ožegović“, Varaždin, 1995. 
kojim su zadani temelji Narodne čitaonice, danas Gradske knjižnice i čitaonice „Metel Ožegović“" Varaždin. ${ }^{39}$ Na njegovo su vlastelinstvo Bela dolazile najznačajnije osobe iz kulturnog i političkog života Hrvatske, ${ }^{40}$ među njima Josip Juraj Strossmayer koji je u kapelici Majke Božje u Beli služio svetu misu 1880. godine. ${ }^{41}$ $\mathrm{Na}$ posjedu su se održavale glazbene večeri i umjetničke priredbe, čitala su se književna djela i recitirala se poezija, dakle vodio se bogati plemićki život. ${ }^{42}$

Metel Ožegović bio je izuzetno pobožna osoba te veliki patron Župe svete Margarete u Margečanu. Obitelj je Ožegović materijalno pomagala Župu, imala je utjecaj na imenovanje župnika te življenjem vjere djelovala poticajno na ostale župljane. ${ }^{43}$ Za služenje svete mise za pokojnoga oca Metel Ožegović darivao je novčani iznos Župi te je utemeljio u tu svrhu Oltarnu zakladu (Fundatio altaristica Osegovichiana) 1841. godine. ${ }^{44}$ Godine 1879. sličnu je Misnu zakladu utemeljio za pokoj duše supruge svoje blagopokojne grofice Ivane, rođene Sermage te odredio da se svake godine u kapelici u Beli za nju služe tri tihe svete mise, jedna na dan njezine smrti (14. veljače), druga na njezin imendan (16. svibnja) i treća na dan njezina krštenja (15. prosinca). ${ }^{45}$

Godine 1885. i 1886. označile su posljednje razdoblje Metelova boravka u Beli. Tada razočaran prilikama u Hrvatskoj odlazi u Hietzing pokraj Beča, a Belu predaje sinu Ljudevitu na upravljanje. ${ }^{46}$

109; Rudolf HORVAT, „Ožegović Barlabaševački bar. Metel“, Znameniti i zaslužni Hrvati te pomena vrijedna lica u hrvatskoj povijesti od 925 - 1925, urednik Emilij LASZOWSKI, Odbor za izdanje knjige „Zaslužni i znameniti Hrvati 925 - 1925“, Zagreb, 1925., 204; Ivančica JEŽ, „Varaždinsko 'Družtvo narodno' - prva hrvatska narodna čitaonica (1838. - 1848.)“, Vjesnik bibliotekara Hrvatske, vol. 53, br. 1, Hrvatsko knjižničarsko društvo, Zagreb, 2010., 123.

39 Ivančica JEŽ, „Neka obilježja preporodnog razdoblja nacionalnog pokreta u Varaždinu (1838. - 1848.)“" Historia Varasdiensis: časopis za varaždinsku povjesnicu, vol. 1, br. 1, Društvo povjesničara grada Varaždina i Varaždinske županije, Varaždin, 2011., 153 - 154.

40 M. OBAD ŠĆITAROCI, n. dj., 41.

${ }_{41}$ ŽUM, Spomenica Župe svete Margarete Margečan, svezak I. (1724. - 2000.), zapis za 1880. godinu, str. $39-40$.

42 D. BIŠĆAN, "Zapisi o Beli“, 99; Tomislav ĐURIĆ, Dragutin FELETAR, Stari gradovi i dvorci sjeverozapadne Hrvatske, drugo dopunjeno izdanje, NIŠRO Varaždin, Varaždin, 1981., 107.

43 Andrija LUKINOVIĆ, Župa Margečan, Župni ured Margečan, Margečan, 1998., 7, 31 - 33.

44 ŽUM, Spomenica Župe svete Margarete Margečan, svezak I. (1724. - 2000.), zapisi za 1841. godinu, str. 15, 20.

45 ŽUM, Spomenica Župe svete Margarete Margečan, svezak I. (1724. - 2000.), zapis za 1879. godinu, str. $41-42$.

46 Arhiv HAZU, Fond obitelji Ožegović, Acta Ožegovićiana, sign. OXL-37, Koncept pisma Metela Ožegovića nepoznatom svećeniku, Bela, p. 1885. godine. 


\section{LJUDEVIT OŽEGOVIĆ I NJEGOV SIN METEL MLAĐI}

Ljudevit Ožegović (Varaždin, 28. veljače 1841. - Zagreb, 28. listopada 1913.) u prvom je redu upravljao imanjima Guščerovec i Veliki Kalnik. ${ }^{47}$ Preuzimanjem brige o Beli uz gospodarenje nad imanjem nastavio je s očevim radom u zajednici. Održavao je pokroviteljstvo nad Župom Margečan te je dao novčani prilog za obnovu župnoga dvora. ${ }^{48}$ Nedugo nakon odlaska iz Bele Metel Ožegović umro je u Hietzingu. Prema očevoj želji Ljudevit Ožegović dao je u Belu prenijeti posmrtne ostatke svojih roditelja. ${ }^{49} \mathrm{Za}$ njih je dao urediti grobnicu u kapelici Majke Božje u Beli. ${ }^{50}$ Njihovo je posljednje počivalište obilježeno kamenom pločom s epitafom na latinskom jeziku čija su slova do današnjih dana prilično izblijedjela. ${ }^{51}$ Prije dolaska obitelji Ožegović kapelica Majke Božje u Beli bila je područna kapelica Župe Margečan, a za vrijeme Ožegovića postala je njihova obiteljska grobnica uklopljena u posjed. ${ }^{52}$ Nakon Metela i Ivane Ožegović postupno su tu sahranjivani i drugi članovi obitelji koje ona čuva do današnjih dana.

47 Ozren BLAGEC, Gordana ĐURIČIĆ, „Ljudevit barun Ožegović“, Cris: časopis Povijesnog društva Križevci, XIV/1, Povijesno društvo Križevci, Križevci, 2012., 142 - 143.

48 ŽUM, Spomenica Župe svete Margarete Margečan, svezak I. (1724. - 2000.), zapis za 1890. godinu, str. 51.

49 OŠ Metel Ožegović, Spomenica Osnovne škole Metel Ožegović Radovan, knjiga I. (1883. - 1919.), Poviest škole, str. 43 - 44; Arhiv HAZU, Fond obitelji Ožegović, Acta Ožegovićiana, sign. OXL-38, Pismo Ljudevita Ožegovića Franji Markoviću, Hietzing, 1. srpnja 1890. godine.

50 U Spomenici Župe svete Margarete Margečan str. 51 opisan je prijenos posmrtnih ostataka Metela i Ivane Ožegović u Belu: Dne 29. rujna 1890. prenešene su kosti iz groblja u Hietzingu kraj Beča preuzvišenoga gospodina baruna Metela Ožegovića i njegove supruge Ivane rođene grofice Sermage. Prijenos je bio posve na tiho i jednostavno prema želji njegovoga sina baruna Ljudevita koji dade prenesti kosti svojih roditelja na svoj trošak $i$ sahrani ih u grobnicu kapele bielske koju je dao iste godine sazidati. Kod sahranjivanja, prem je bilo skromno, ipak je prisustvovalo mnogo domaćih župljanah i otmenije gospode.

51 Prijevod epitafa Metelu Ožegoviću: U ovom Božjem domu sjedinjen je s vječnim mirom barun Metel Ožegović od Barlabaševca i Bele, njegovog carskog i kraljevskog veličanstva pouzdanik i državni savjetnik, nosilac ordena cara Leopolda itd. itd. Rođen 4. svibnja 1814. Umro 9. veljače 1890. (...). (Prijevod epitafa Metelu Ožegoviću u cijelosti donosi: Drago BIŠĆAN, „Epitaf na grobu Metela Ožegovića u Beli“, Godišnjak Gradske knjižnice i čitaonice "Metel Ožegović" Varaždin, god. 1, br. 1, Gradska knjižnica i čitaonica „Metel Ožegović“, Varaždin, 1995., 105). Na epitaf Metelu Ožegoviću nastavlja se epitaf Ivani Ožegović također na latinskome jeziku koji u prijevodu glasi: (Metel Ožegović) pokopan je sa svojom preljubljenom suprugom Ivanom rođenom groficom Sermage od Susedgrada i Medvedgrada, rođenom 13. prosinca 1811. godine, a umrlom 14. veljače 1878. godine, koja bijaše vjerna supruga svome mužu s njime dijeleći slavu $i$ čast, i njegova najdostojnija pomoćnica i u najnemirnijim vremenima $u$ državi, (bijaše) najvjernijom ženom i najboljom majkom, odrazom čistoće životnih vrlina, čiju su smrt svi, koji su je poznavali, popratili suzama, a najviše od svih doista neutješan suprug i pretužna djeca. Na ovom najsvetijem mjestu za vječnost združenima daj im vječno svjetlo, Gospodine. Amen. (Prijevod autorice).

52 A. LUKINOVIĆ, n. dj., 76, 81. 
S prvom suprugom Olgom rođenom Erdödy Ljudevit Ožegović imao je četvero djece: Ivana, Metela Mlađeg, Miroslava i Ivanu udanu Daubachy Doljska ${ }^{53}$ koja je imala posjed u Cerju Nebojse, naselju nedaleko Bele..$^{54}$ Od Olge Erdödy razveo se oko 1895. godine te se ponovno oženio Ivkom Hayos/Hiršl koja je bila židovske vjere i radila je kao učiteljica u Koprivnici..$^{55}$ Taj se postupak odrazio na obiteljske prilike i upravljanje Belom. Obitelj se Ožegović otuđila od Ljudevita koji je s novom suprugom i kćerkom Lucijom rođenom 1896. godine živio na svojem imanju u Guščerovcu, a potom u Zagrebu. ${ }^{56}$ Ljudevit Ožegović umro je u listopadu 1913. godine te je pokopan u Beli. Njegov je grob u kapelici Majke Božje obilježen spomenikom. S njime nije sahranjena nijedna od njegovih supruga. Pogrebu Ljudevita Ožegovića, koji je održan 1. studenoga 1913. godine, prisustvovali su članovi pokojnikove obitelji, okolna aristokracija, pročelnici raznih oblasti i mnoštvo naroda. ${ }^{57} \mathrm{Na}$ pogreb u Belu također su došle njegova supruga Ivka i kćer Lucija. ${ }^{58}$

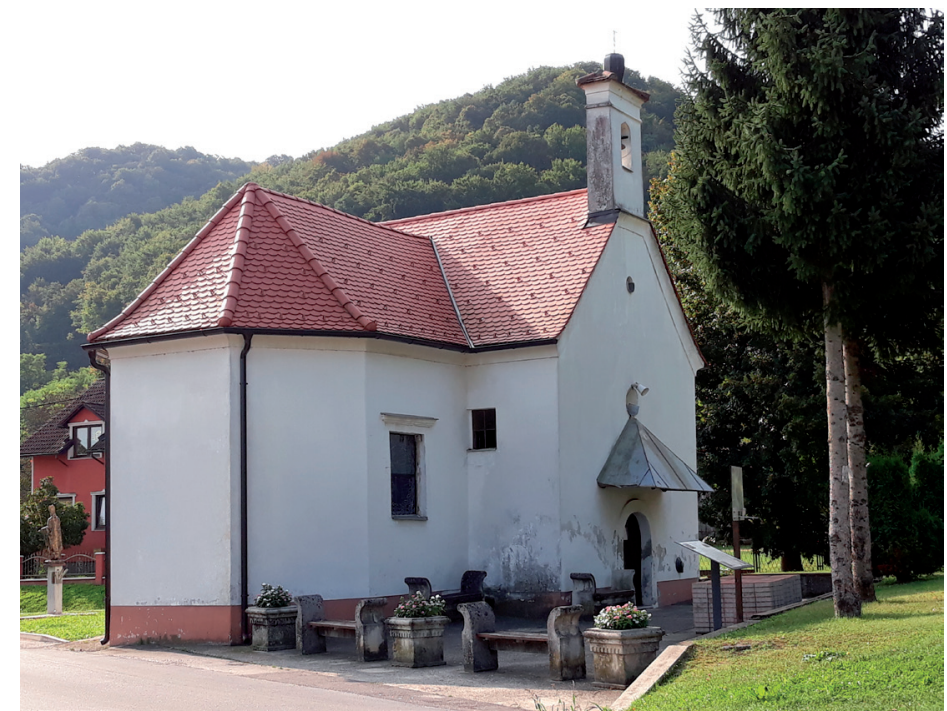

Slika 5. Kapelica Majke Božje u Beli u kojoj su sahranjeni članovi obitelji Ožegović (FOTO: Ana Škriljevečki).

53 GMV, Povijesni odjel, inv. br. GMV 81571, Osmrtnica barunice Olge Ožegović.

54 S. BELOŠEVIĆ, n. dj., 104.

55 O. BLAGEC, G. ĐURIČIĆ, n. dj., 143.

56 Lucija OŽEGOVIĆ, Pismo mrtvom sinu, Zora, Zagreb, 1953., 9 - 17, 20 - 21; Lucija KONFIC, „Lucija Ožegović - život i karijera obilježeni ulogom majke", Cris: časopis Povijesnog društva Križevci, XIV/1, Povijesno društvo Križevci, Križevci, 2012., 45.

57 „Domaće vijesti“" Naše pravice, 6. studenoga 1913., br. 46, str. 4.

58 L. OŽEGOVIĆ, n. dj., 36. 
Dvojica sinova Ljudevita Ožegovića, Metel Mlađi i Ivan, upravljali su Belom za vrijeme života svojega oca. Međutim, ne zna se od koje su točno godine preuzeli upravljanje belskim posjedom. Moguće da se radilo o 1895. godini kada je Ljudevit osnovao novu obitelj. Metel Ožegović Mlađi (Guščerovec, 9. travnja 1867. - Križevci, 27. siječnja 1904.), ${ }^{59}$ najstariji sin Ljudevita i Olge, navodi se u rodoslovlju koje je dao izraditi 1899. godine kao belski vlastelin. ${ }^{60}$

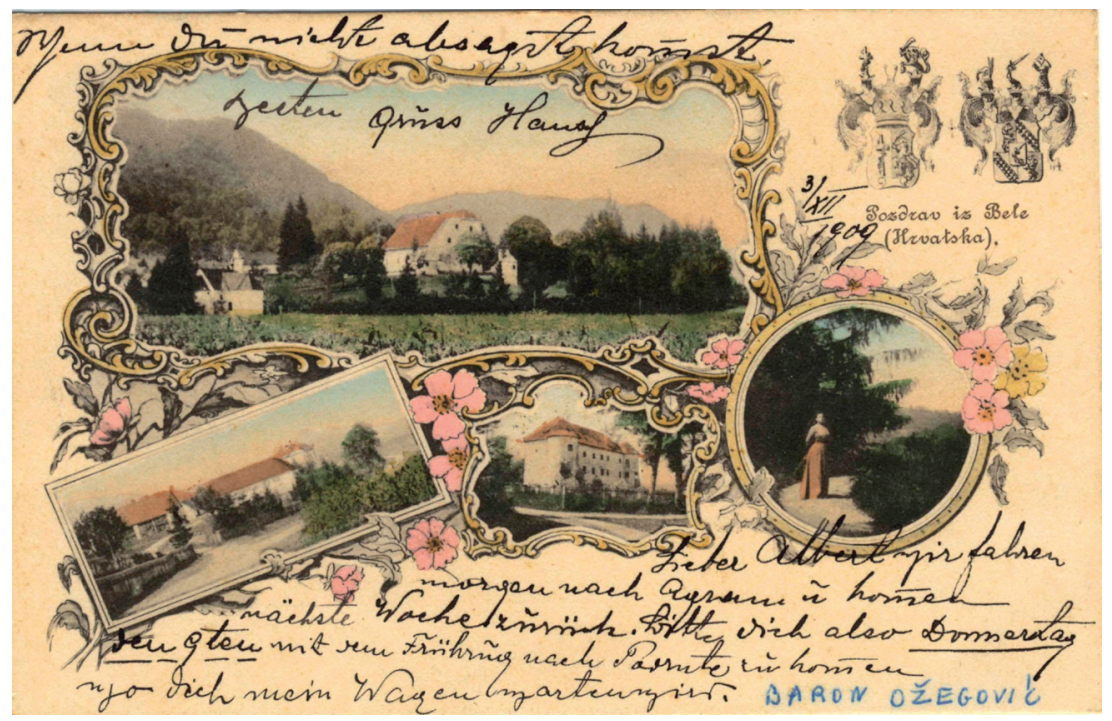

Slika 6. Pozdrav iz Bele (Hrvatska), 3. prosinca 1909. godine, razglednica

(Gradska knjižnica i čitaonica Novi Marof).

Metel Mlađi gospodario je posjedom na način koji su započeli njegov djed i pradjed. Nastavio je održavati pokroviteljstvo nad Župom svete Margarete. Kod izvora vode u Belskome dolu podno utvrde Pusta Bela dao je postaviti i blagosloviti kip Blažene Djevice Marije te novčani iznos za njegovo uzdržavanje. ${ }^{61}$ Danas je na tome mjestu kapelica Majke Božje u Belskome dolu, a ne zna se što se dogodilo

59 GMV, Povijesni odjel, inv. br. GMV 81563 i GMV 81563-1, Osmrtnice baruna Metela Ožegovića; Kapela Majke Božje u Beli, Spomenik na grobu Metela Mlađeg Ožegovića, 1904. godina.

60 GMV, Povijesni odjel, inv. br. GMV PO 4049, Rodoslovlje Metela Ožegovića Barlabaševačkog i Belskog, 1899. godina. Od Metela Ožegovića Mlađeg granaju se njegovi preci s očeve i majčine strane uz pripadajuće grbove.

61 ŽUM, Spomenica Župe svete Margarete Margečan, svezak I. (1724. - 2000.), zapis za 1898. godinu, str. 59. 
s navedenim kipom..$^{62}$ Međutim, Metel Mlađi nije bio u dobrim odnosima s belskim župnikom Jurajom Čvekom koji je aktivno podupirao pravaše, a Metel Mlađi bio je pak naklonjen mađaronima. ${ }^{63}$ Imanje su nastavile posjećivati plemićke obitelji povezane s obitelji Ožegović. Belske su šume bile bogato lovište u koje su često odlazili gosti obitelji. ${ }^{64}$ Metel Mlađi bio je oženjen za groficu Adrienu rođenu Neuhaus ${ }^{65}$ s kojom nije imao djece. Bela nije bio jedini posjed na kojem su boravili jer je Metel Mlađi djelovao kao carski i kraljevski komornik te kraljevski kotarski predstojnik u Križevcima gdje je umro u mladoj dobi. Pokopan je u obiteljskoj grobnici u Beli. ${ }^{66}$ Adriena se preudala te nije sahranjena s prvim suprugom.

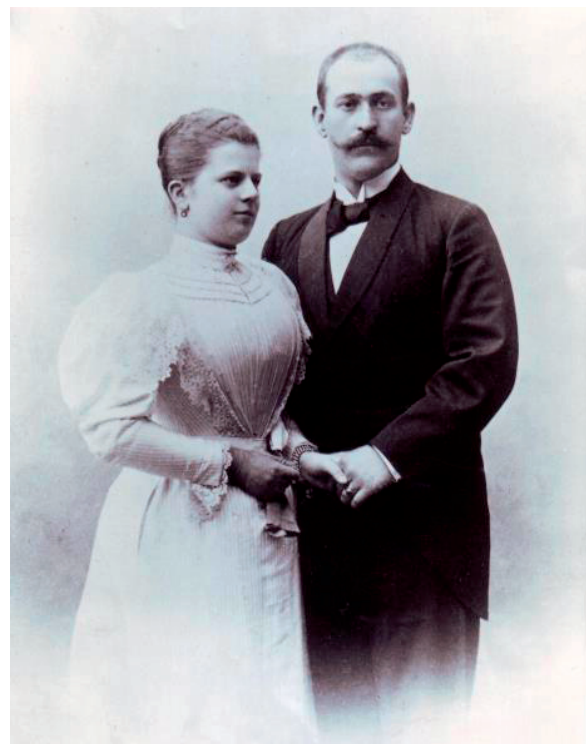

Slika 7. Metel Mlađi sa suprugom Adrienom rođenom Neuhaus, kraj 19. ili početak 20. stoljeća, fotografija (Gradska knjižnica i čitaonica "Metel Ožegović" Varaždin).

62 A. LUKINOVIĆ, n. dj., $118-119$.

63 ŽUM, Spomenica Župe svete Margarete Margečan, svezak I. (1724. - 2000.), zapis za 1897. godinu, str. 56; A. LUKINOVIĆ, n. dj., 152.

64 Varaždinski viestnik izvijestio je o nesreći koju je Metel Mlađi doživio na povratku iz lova s potpukovnikom ulanske pukovnije Helfom i grofom Jelačićem (nije riječ o banu Jelačiću, koji je umro 1859. godine, nego o drugom članu obitelji Jelačić). U nesreći kolima grof i barun pretrpjeli su teške tjelesne ozljede („Domaće viesti“, Varaždinski viestnik, 11. listopada 1890., br. 36, str. 2).

65 GMV, Galerija starih i novih majstora, inv. br. GMV GS 501, Portret Adriene Ožegović, nepoznat autor, 19. stoljeće s natpisom: Adrienna Comitissa Neyhausz Ab St. Mauro Uxor Metelli Jun Liberi Baronis Osegovich Nat. 1872. Na hrvatskome jeziku tekst natpisa glasi: Adriena grofica Neuhaus od San Maura, supruga Metela Mlađeg baruna Ožegovića, rođena 1872. godine. (Prijevod autorice).

66 GMV, Povijesni odjel, inv. br. GMV 81563 i GMV 81563-1, Osmrtnice baruna Metela Ožegovića; „Domaće viesti“", Naše pravice, 4. travnja 1904., br. 1, str. 6. 


\section{IVAN I ADELA OŽEGOVIĆ}

Nakon smrti Metela Ožegovića Mlađeg upravljanje Belom u potpunosti preuzima njegov brat Ivan Ožegović (Zagreb, 12. siječnja 1872. - Varaždin, 4. studenoga 1941., sahranjen u kapelici Majke Božje u Beli). ${ }^{67}$ Ivan Ožegović bio je kraljevski perovodni vježbenik u Novome Marofu. Godine 1892. imenovan je kraljevskim kotarskim pristavom II. razreda (pomoćnim sudskim službenikom). ${ }^{68} \mathrm{U}$ Beli je živio sa suprugom Adelom Ožegović (Varaždin, 11. ožujka 1878. - Bela, 28. studenoga 1950.), koja potječe iz varaždinske patricijske obitelji Tomasi od Beroldinga, ${ }^{69}$ te sinovima Ivanom Nepomukom (zvanom Hansi) i Metelom. Ivan Nepomuk Ožegović (rođen u Varaždinu 1. svibnja 1899.) ${ }^{70}$ bio je artiljerijski potporučnik u vojsci, a njegov brat Metel Ožegović (rođen 18. studenoga 1908., pogubljen 29. lipnja 1945. u Tužnom $)^{71}$ polazio je križevačku gospodarsku školu. ${ }^{72}$

Ivan Ožegović je poput svojih prethodnika upravljao čitavim belskim vlastelinstvom. Glavni je objekt na imanju bio stariji dvorac u kojem je živjela obitelj dok je mlađi dvorac ostao zapostavljen. ${ }^{73} \mathrm{U}$ vrijeme Ivana Ožegovića belski je posjed gospodarski bio izuzetno razvijen. Na imanju su bile uređene gospodarske zgrade za držanje stoke, vrt, voćnjak, ribnjak i novootvorena pilana na mlin. ${ }^{74}$ Ivan Ožegović bio je predsjednik županijskog carskog povjerenstva za stočarstvo (marvogojstvo). Uzgajao je čistokrvna simentalska goveda na imanju i sudjelovao je na izložbama. Za svoju je stoku na izložbi u Beli 19. studenoga 1917. godine dobio zlatnu nagradu. ${ }^{75}$ Godine 1924. osnovao je Marvogojsku udrugu u Beli koja je za oplemenjivanje domaćih goveda uvozila rasplodne bikove iz švicarskih i

67 ŽUM, Status animarum Župe svete Margarete Margečan, svezak I., str. 71; GMV, Povijesni odjel, inv. br. GMV 81566, Osmrtnica Ivana baruna Ožegovića od Barlabaševac i Bela.

68 „Domaće viesti“, Varaždinski viestnik, 23. srpnja 1892., br. 30, str. 2.

69 ŽUM, Status animarum Župe svete Margarete Margečan, svezak I., str. 71; GMV, Povijesni odjel, inv. br. GMV 81564, Osmrtnica Adele Ožegović Barlabaševačke i Belske; S. BELOŠEVIĆ, n. dj., 116; Branko SVOBODA, Stare vinogradarske kurije i kleti, Kulturno-prosvjetno društvo hrvatskih Zagoraca „Matija Gubec“, Zagreb, 1967., 679.

70 ŽUM, Status animarum Župe svete Margarete Margečan, svezak I., str. 71.

71 ŽUM, Spomenica Župe svete Margarete Margečan, svezak I. (1724. - 2000.), Dodatak Spomenici: Poginuli i nestali u Prvom i Drugom svjetskom ratu, poraću i Domovinskom ratu, str. 308.

72 S. BELOŠEVIĆ, n. dj., 116.

73 Milan KUČENJAK, n. dj., 2; Gjuro SZABO, Sredovječni gradovi u Hrvatskoj i Slavoniji, Matica hrvatska, Zagreb, 1920., 86.

74 I. NJEGOVEC, „Ožegovićeva 'kalvarija', Sudbine zagorskih dvoraca i njihovih vlasnika“, (Intervju s Ljubom Banić, sobaricom obitelji Ožegović u Beli i Ivanom Lekše rođenom Ožegović), $V a-$ raždinske vijesti, 20. rujna 1990., br. 37, str. 12; „Oglas: Pilana (na mlin) ustrojena po vlastelinstvu Bela (bar. Ivana Ožegovića)“, Hrvatske pravice, 5. ožujka 1910., br. 10, str. 6.

75 „Iz okolice“, Hrvatsko pravo, 15. prosinca 1917., br. 50, str. 2; „Narodno gospodarstvo, Nagrađivanje stočara", Narodno jedinstvo, 19. studenoga 1921., br. 15, str. 7. 
austrijskih zemalja. ${ }^{76}$ Vlastelina su cijenili njegovi radnici i lokalni seljaci, koje je često savjetovao oko gospodarskih i imovinskih pitanja, te su se usprotivili kad mu je 1926. godine agrarnom reformom zemljište trebalo biti oduzeto i dano $u$ zakup. $^{77}$

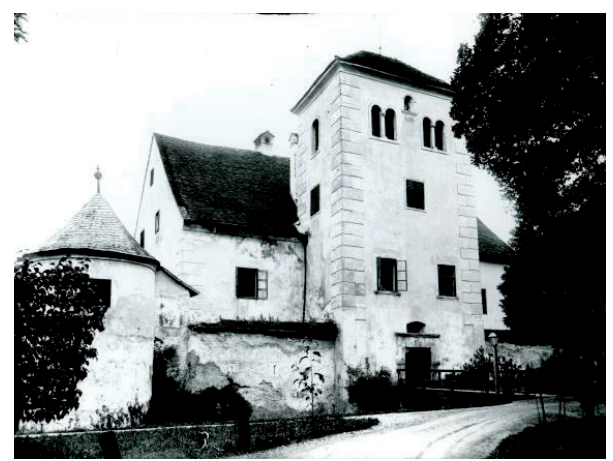

Slika 8. Pogled na dvorac Bela I, 1920ih, presnimak (Gradski muzej Varaždin, Kulturnopovijesni odjel, Zbirka fotografija i razglednica, inv. br. 87265).

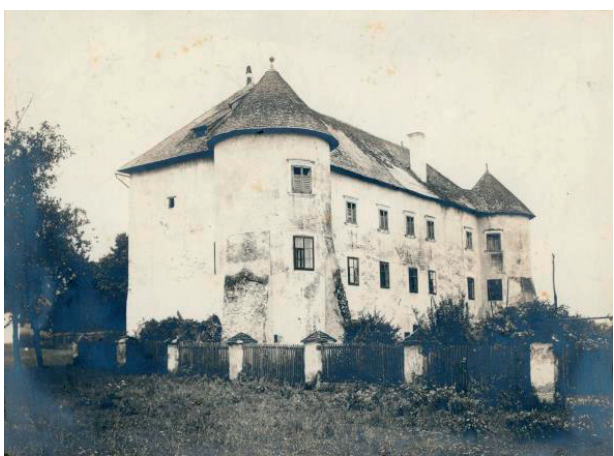

Slika 9. Dvorac Bela II, 1930-ih, fotografija, fotograf Đuro Szabo? (Gradski muzej Varaždin, Kulturnopovijesni odjel, Zbirka fotografija i razglednica, inv. br. 87256).

Ivan Ožegović također je nastavio izvršavati svoje kolatorske obveze u Župi Margečan. Imao je utjecaj na odluku o imenovanju Ludovika Slamnika župnikom 1935. godine. ${ }^{78}$ Također je brinuo o razvoju školstva. Obnašao je dužnost mjesnog školskog nadzornika i predsjednika školskog odbora u pučkoj školi u Radovanu. Za kraj školske godine 1906. učenike je nagradio novčanim iznosom i jednim prasetom iz Bele. ${ }^{79}$ Nakon Ivanove smrti, njegova supruga Adela ostaje živjeti na imanju, a brigu o njemu preuzeli su njegovi sinovi. ${ }^{80}$

76 M. STANKUS, „Ožegovići unaprijedili stočarstvo našeg kraja“, Varaždinske vijesti, 15. siječnja 1992., br. 2, str. 6.

77 S. BELOŠEVIĆ, n. dj., 115 - 116.

78 ŽUM, Spomenica Župe svete Margarete Margečan, svezak I. (1724. - 2000.), zapis za 1939. godinu, str. 114.

79 OŠ Metel Ožegović, Spomenica Osnovne škole Metel Ožegović Radovan, knjiga I. (1883. - 1919.), str. 35, 108.

80 GMV, Povijesni odjel, inv. br. GMV 94405, Zahvalnica Adele Ožegović Krešimiru Filiću povodom smrti supruga, Bela, studeni 1941. godine; I. NJEGOVEC, „Ožegovićeva 'kalvarija', Sudbine zagorskih dvoraca i njihovih vlasnika", 12. 


\section{IVAN NEPOMUK I METEL OŽEGOVIĆ, SINOVI IVANA I ADELE}

Godine koje su uslijedile nakon smrti Ivana Ožegovića označile su početak razdoblja stradanja obitelji Ožegović koje je dovelo do propadanja belskoga vlastelinstva. U to je vrijeme na imanju uz Adelu i Ivana Nepomuka boravila obitelj njezinoga mlađeg sina Metela. Metel Ožegović je sa suprugom Emilijom rođenom Ruiz de Roxas (rođena 24. studenoga 1903., pogubljena 29. lipnja 1945. u Tužnom) imao dvoje djece, Ivanu (rođena 31. srpnja 1931.) i Janka (rođen 12. siječnja 1933.). ${ }^{81}$

Od 1943. godine obitelj je trpjela premetačine partizana u Beli čega je posljedica preseljenje pojedinih članova iz Bele u palaču Ožegović-Tomasi preko puta župne crkve svetoga Nikole u Varaždinu. ${ }^{82}$ Za vrijeme rata Metel je imao funkciju niže rangiranog domobranskog časnika stacioniranog u konjičkoj kasarni u Optujskoj ulici u Varaždinu. U svibnju 1945. godine odveden je sa suprugom Emilijom u varaždinski zatvor pod optužbama špijuniranja za Gestapo i članstva u Kulturbundu te su nakon prijekog suda oboje pogubljeni 29. lipnja 1945. godine u predjelu Drvarićeva šuma u naselju Tužno udaljenom oko sedam kilometara od njihove Bele. ${ }^{83}$ Jedina pronađena poveznica Metela Ožegovića s Njemačkom njegovo je članstvo u Društvu prijatelja Njemačke u Varaždinu. Svrha je Društva bila održavanje prijateljskih odnosa s njemačkim narodnom. Metel i Ivan Ožegović (Metelov brat ili otac) prisustvovali su konstituirajućoj skupštini Društva u Varaždinu u listopadu 1940. godine. ${ }^{84}$

Obitelji Ožegović oduzet je znatan dio imovine. Stariji je dvorac odmah nakon rata nacionaliziran. ${ }^{85}$ Sačuvane portrete iz dvorca obitelj je darovala Grad-

81 ŽUM, Status animarum Župe svete Margarete Margečan, svezak I., str. 71; Spomenica Župe svete Margarete Margečan, svezak I. (1724. - 2000.), Dodatak Spomenici: Poginuli i nestali u Prvom i Drugom svjetskom ratu, poraću i Domovinskom ratu, str. 308.

82 I. NJEGOVEC, „Ožegovićeva 'kalvarija', Sudbine zagorskih dvoraca i njihovih vlasnika“, 12 ; I. NJEGOVEC, „Morat će mi vratiti oduzeto, Sudbine zagorskih dvoraca i njihovih vlasnika (III)“, (Intervju s Jankom Ožegovićem), Varaždinske vijesti, 27. rujna 1990., br. 38, str. 10.

83 „Plan o hapšenju narodnih neprijatelja po grupama za grad Varaždin“, Opunomoćeništvo OZN-a II. zagrebačke oblasti za okrug Varaždin, 31. ožujka 1945. godine. Među „narodnim neprijateljima“ popisani su: barunica Ožegović, obavještajac gestapoa za općinu Vidovec i Ožegović barun Metil, istaknuti član kulturbunda. Dokument naveden u: Vladimir GEIGER et al., Partizanska i komunistička represija $i$ zločini u Hrvatskoj 1944. - 1946.: dokumenti 3, Zagreb i Središnja Hrvatska, Hrvatski institut za povijest, Podružnica za povijest Slavonije, Srijema i Baranje, Hrvatski institut za povijest, Slavonski Brod - Zagreb, 2008., 231; U članku "Narodne neprijatelje stiže zaslužena kazna“, Varaždinske vijesti, 7. srpnja 1945., br. 8, str. 3 navodi se: Vojni sud u Varaždinu osudio je na kaznu smrti strijeljanjem, trajan gubitak građanskih časti i zapljenu imovine sljedeće ratne zločince i špijune Gestapoa (...). Među osuđenima popisani su barun Metel Ožegović i njegova supruga barunica Emilija Ožegović.

84 "Društvene vijesti“, Varaždinske novosti, 10. listopada 1940., br. 567, str. 5.

85 M. OBAD ŠĆITAROCI, n. dj., 40. 
skom muzeju Varaždin. Ivan Nepomuk Ožegović nastavio je živjeti u mlađem dvorcu. O Ivani i Janku brinula je njihova baka Adela Ožegović i njezin brat Ljudevit Tomasi u Varaždinu. ${ }^{86}$ Adela Ožegović umrla je u siromaštvu te je prema osmrtnici sahranjena u obiteljskoj grobnici u Beli kao posljednja članica obitelji Ožegović koja je tamo pokopana, ali njezin nadgrobni spomenik, za razliku od onog njezina supruga, nije označen u kapelici. Tijekom agrarne reforme za Ivana Nepomuka Ožegovića svjedočio je bivši radnik pred agrarnom komisijom da radi na imanju kako bi se smatrao zemljoradnikom i ne bi mu bio oduzet čitav posjed. ${ }^{87} \mathrm{No}$, agrarnom je reformom Ivan Nepomuk Ožegović ipak izgubio velike dijelove imanja, čega je posljedica bila nemogućnost izvršavanja kolatorske obveze i prestanak patronata nad Župom Margečan. O kapelici Majke Božje u Beli ponovno je od 1952. godine brinula Župa. ${ }^{88}$

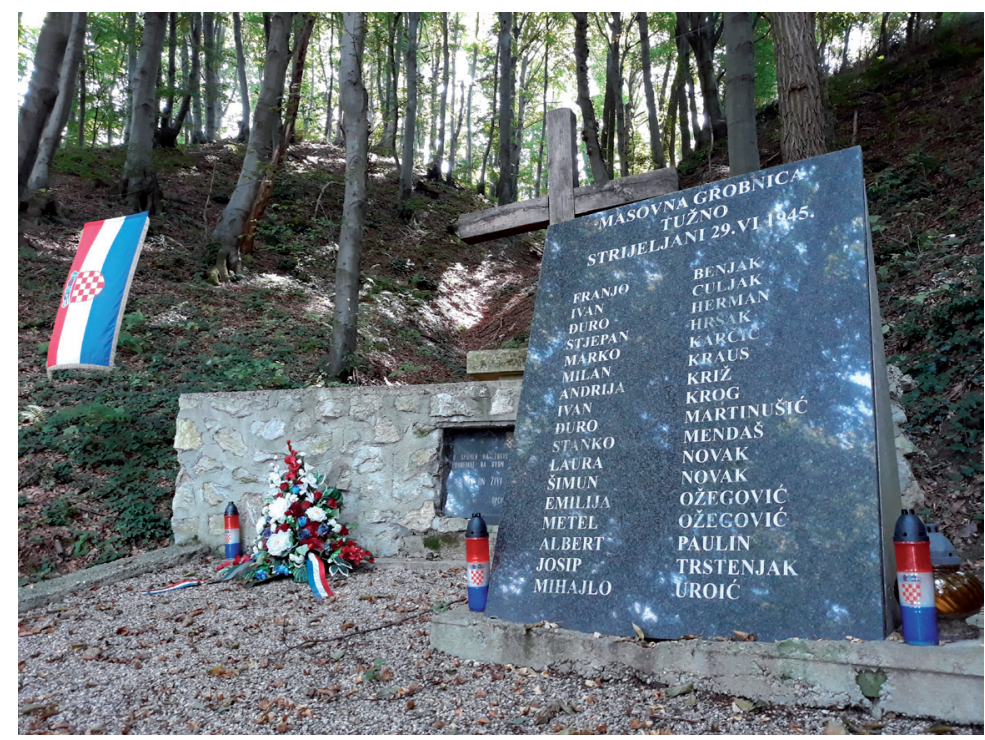

Slika 10. Masovna grobnica Drvarićeva šuma, Tužno ${ }^{89}$ (FOTO: Ana Škriljevečki).

86 I. NJEGOVEC, „,Ožegovićeva 'kalvarija', Sudbine zagorskih dvoraca i njihovih vlasnika“, 12; I. NJEGOVEC, „Morat će mi vratiti oduzeto, Sudbine zagorskih dvoraca i njihovih vlasnika (III)“, 10.

87 S. B. „Kako se zagorski vlastelini bore protiv agrarne reforme“, Varaždinske vijesti, 6. lipnja 1946., br. 55 , str. 2 .

88 ŽUM, Spomenica Župe svete Margarete Margečan, svezak I. (1724. - 2000.), zapis za 1952. godinu, str. 119.

89 Grobište u Drvarićevoj šumi obilježeno je u studenome 1997. godine. Obilježavanje je izvršilo Istraživačko središte Varaždin, Komisija za utvrđivanje ratnih i poratnih žrtava II. svjetskog rata s članovima obitelji žrtava, preživjelih svjedoka i mjesnog župnika („Obilježena grobišta“, Varaždinske vijesti, 3. prosinca 1997., br. 49, str. 17). 


\section{ODLAZAK OBITELJI OŽEGOVIĆ IZ BELE}

Ivan Nepomuk Ožegović sa suprugom Marijom rođenom Goričan odselio je 1958. godine iz dvorca Bela II u Zagreb..$^{90}$ Posjed je prodao općini Novi Marof koja ga je prvotno predala na korištenje vojsci. U Beli II logorovala je predvojnička mladež. Od rujna 1958. godine stariji je dvorac Bela I koristila Osnovna škola Završje. U njemu su bili stanovi prosvjetnih radnika, ravnatelja škole i radio stanica. Krajolik oko dvorca i gospodarske zgrade uređeni su za potrebe škole. ${ }^{91}$ Sklop Bela I, dvorac s perivojem, vraćen je Ivani i Janku Ožegoviću koji su ga 2004. godine prodali privatnoj osobi. ${ }^{22}$ Bela II od 2004. godine također je u privatnome vlasništvu, a krajolik oko dvorca od agrarne je reforme podijeljen na sitne čestice kojima gospodari više vlasnika. ${ }^{93}$ Mnogobrojne promjene vlasništva i namjene posjeda nakon Ožegovića te neprimjerena briga i nemar rezultirali su propadanjem dvoraca. Obnova mlađeg dvorca pokrenuta je 2004. godine, ali nije provedena u cijelosti. Stariji dvorac, koji je stavljen u prodaju, u ruševnom je stanju te iz dana u dan sve više propada.

\section{ZAKLJUČAK}

Prateći kronološki život obitelji Ožegović u Beli prema dostupnim izvorima, osvijetljeni su dijelovi povijesti vlastelinstva koji su dosada bili nepoznati. Pritom se prije svega misli na razdoblje od 1817. do 1858. godine koja se tradicionalno prva dovodila u vezu s Belom i Ožegovićima. Zahvaljujući prijevodima dokumenata i natpisa spomenika s latinskog jezika otkrivena je rodbinska povezanost s obiteljima, koje su naslijedile Belu, i njezin utjecaj na način kupnje belskoga posjeda, te postupak nasljeđivanja posjeda unutar obitelji Ožegović.

Ožegovići su imanje ujedinili pod svojim upravljanjem, gospodarski unaprijedili i kulturno oživjeli, što je odraz njihovog statusa ugledne hrvatske plemićke obitelji. Njihov je društveni rad u kraju nezamjenjiv, posebice na području škol-

90 ŽUM, Spomenica Župe svete Margarete Margečan, svezak I. (1724. - 2000.), zapis za 1958. godinu, str. 138: Barun Ivan i njegova supruga Marija (djece nemaju) odselili su ovog proljeća u Zagreb, pošto su prije prodali gospodarske zgrade i stari dvorac u kojem su stanovali. Zemlju su međutim zadržali $i$ dali $u$ arendu.

91 ŽUM, Spomenica Župe svete Margarete Margečan, svezak I. (1724. - 2000.), zapis za 1958. godinu, str. 138; T. ĐURIĆ, „Pjesma i ples ispod Belskih zidina“, Varaždinske vijesti, 5. lipnja 1971., br. 21, str. 11 .

92 Josip HABUNEK, Prehrana ljudi radovansko-bielskog kraja u prošlosti, Društvo prijatelja glazbe i narodnih običaja „Lompuš“ Radovan, Radovan, 2004., 9.

93 Dubravko HOIĆ, Dubravka HOIĆ, „Gospodarska održivost projekta revitalizacije dvorca Bela II", Suvremeno korištenje i kreativno upravljanje dvorcima, kurijama i ljetnikovcima, zbornik radova Međunarodnog znanstveno-stručnog skupa održanog 10. studenoga 2005. godine u Zagrebu, urednik Nikša Božić, Arhitektonski fakultet Zagreb, Zagreb, 2005., 147. 
stva i vjere, od čega je korist imala cijela zajednica. Velik je nesrazmjer između djelovanja obitelji Ožegović i tragičnih događaja koji su uslijedili 1945. godine. Tim je veća odgovornost na nama da njegujemo njihovo nasljeđe u Beli i vrijednosti koje su cijenili. Stoga je ovaj rad mali doprinos tome cilju. Njime su ujedno otvorene mogućnosti za daljnja istraživanja koja će nesumnjivo donijeti nova saznanja o djelovanju obitelji Ožegović, ne samo na vlastelinstvu Bela nego u čitavom belsko-radovanskom kraju.

\section{IZVORI}

1. Arhiv Hrvatske akademije znanosti i umjetnosti, Fond obitelji Ožegović, Acta Ožegovićiana, sign. OXL-37, Koncept pisma Metela Ožegovića nepoznatom svećeniku, Bela, p. 1885. godine; sign. OXL-38, Pismo Ljudevita Ožegovića Franji Markoviću, Hietzing, 1. srpnja 1890. godine; sign. OXXXVIII-23/o, Pismo Ivane Ožegović Metelu Ožegoviću, Bela, 18. kolovoza 1861. godine.

2. Državni arhiv u Varaždinu, Zbirni fond HR-DAVŽ-542 Razne obitelji XVI. XX. stoljeća, kutija 2, broj 17, Ožegović Barlabaševečki (1822. - 1837.), Gorni list izdan Tomi Biškupu od Stjepana Ožegovića Barlabaševečkog za korištenje vinograda, Bela, 10. travnja 1831. godine; Tri gorna lista izdana od Stjepana Ožegovića Barlabaševečkog za korištenje vinograda, Bela, 1831. godine; Priznanica za tristo forinti primljenih po Ani udovi Culifaj rođenoj Marković od šurjaka Stjepana Ožegovića u ime isplate svojega dijela iz imanja Bela, Vadine, 2. siječnja 1822. godine.

3. Gradski muzej Varaždin, Galerija starih i novih majstora, inv. br. GMV GS 501, Portret Adriene Ožegović, nepoznat autor, 19. stoljeće; inv. br. GMV KPO 1989 = GS 790, Portret Stjepana Ožegovića, autor Michael Stroy, 1837. godina.

4. Gradski muzej Varaždin, Povijesni odjel, inv. br. GMV 92254, Pismo podžupana Varaždinske županije Blaža Švagelja upućeno Stjepanu Ožegoviću u Belu, Varaždin, 15. lipnja 1836. godine; inv. br. GMV PO 4049, Rodoslovlje Metela Ožegovića Barlabaševačkog i Belskog, 1899. godina; inv. br. GMV KPO 4836, Samuel MOSINGER, Kratka povjest družtva dobročinstva u Varaždinu, 1870. godina, rukopis; inv. br. GMV 81563, 81563-1, 81564, 81566, 81571, Osmrtnice članova obitelji Ožegović; inv. br. GMV 94405, Zahvalnica Adele Ožegović Krešimiru Filiću povodom smrti supruga, Bela, studeni 1941. godine.

5. Kapela Majke Božje u Beli, Epitaf Metelu i Ivani Ožegović, o. 1890. godine; Spomenik na grobu Metela Mlađeg Ožegovića, 1904. godina; Spomenik Stjepanu Ožegoviću koji su mu posvetili supruga Jozefina rođena Marković i sinovi Metel i Gustav Ožegović, o. 1837. godine.

6. Novine digitalizirane na portalu Novinstvo Varaždina: Hrvatske pravice, god. 1910./br. 10, Hrvatsko pravo, god. 1917./br. 50, Narodno jedinstvo, god. 1921./br. 15, Naše pravice god. 1904./br. 1 i god. 1913./br. 33, Varaždinske novosti, god. 
1940./br. 567, Varaždinske vijesti, god. 1946./br. 55, god. 1971./br. 21, god. 1990./ br. 37 i br. 38, god. 1992./br. 2, god. 1997./br. 49, Varaždinski viestnik god. 1890./ br. 36 i god. 1892./br. 30, Slobodni gradjanin, god. 1921./br. 26.

7. Novine digitalizirane na portalu Stare hrvatske novine, Nacionalna i sveučilišna knjižnica u Zagrebu, 2009.: Ilirske narodne novine god. 1838./br. 99.

8. Novine dostupne u Knjižnici Ministarstva kulture Republike Hrvatske: $\mathrm{Hr}$ vatska prosvjeta: mjesečnik za književnost, umjetnost i prosvjetu, god. 1916./br. 3.

9. Osnovna škola Metel Ožegović Radovan, Spomenica Osnovne škole Metel Ožegović Radovan, knjiga I. (1883. - 1919.).

10. Župna crkva svete Margarete Margečan, Spomen-ploča Stjepanu Ožegoviću koju mu je posvetio sin Metel Ožegović, o. 1837. godine.

11. Župni ured Margečan, Spomenica Župe svete Margarete Margečan, svezak I. (1724. - 2000.) i Dodatak Spomenici: Poginuli i nestali u Prvom i Drugom svjetskom ratu, poraću i Domovinskom ratu; Status animarum Župe svete Margarete Margečan, svezak I.

\section{LITERATURA}

1. Ana BEČEHELI et al., Novi Marof nekad i danas, Grad Novi Marof, Turistička zajednica Grada Novog Marofa, Novi Marof, 2015.

2. Juraj BELAJ, „Bela - ivanovački burg na Ivanščici“, Prilozi Instituta za arheologiju u Zagrebu,vol. 25, br. 1, Institut za arheologiju, Zagreb, 2009., 155 - 182.

3. Stjepan BELOŠEVIĆ, Županija varaždinska i slob. i kralj. grad Varaždin / napisao Stjepan Belošević, Gornjo-Stubički veliki župan Županije varaždinske i slob. kralj. grada Varaždina, Vlastita naklada, Zagreb, 1926.

4. Drago BIŠĆAN, „Epitaf na grobu Metela Ožegovića u Beli“, Godišnjak Gradske knjižnice i čitaonice „Metel Ožegović” Varaždin, god. 1, br. 1, Gradska knjižnica i čitaonica „Metel Ožegović“, Varaždin, 1995., 105.

5. Drago BIŠĆAN, „Zapisi o Beli", Hrvatski kajkavski kolendar 1995., Matica hrvatska Čakovec, Čakovec, 1994., 97 - 101.

6. Ozren BLAGEC, „Bela IV. i kalničko plemstvo“, Cris: časopis Povijesnog društva Križevci, XII/1, Povijesno društvo Križevci, Križevci 2010., 234. - 244.

7. Ozren BLAGEC, ĐURIČIĆ, Gordana, „Ljudevit barun Ožegović“, Cris: časopis Povijesnog društva Križevci, XIV/1, Povijesno društvo Križevci, Križevci, 2012., $142-156$.

8. Ivan BOJNIČIĆ, Der Adel von Kroatien und Slavonien, pretisak prvog izdanja iz 1899. godine, Golden Marketing, Zagreb, 1995.

9. Lelja DOBRONIĆ, Templari i ivanovci u Hrvatskoj, Dom i svijet, Zagreb, 2002. 
10. Tomislav ĐURIĆ, Dragutin FELETAR, Stari gradovi i dvorci sjeverozapadne Hrvatske, drugo dopunjeno izdanje, NIŠRO Varaždin, Varaždin, 1981.

11. Tomislav ĐURIĆ, Dragutin FELETAR, Stari gradovi, dvorci i crkve sjeverozapadne Hrvatske, treće dopunjeno i prerađeno izdanje, Ogranak Matice Hrvatske, Koprivnica, i autori, Koprivnica, 1991.

12. Krešimir FILIĆ, „Stare gradine u Hrvatskom Zagorju“, Zagorski kolendar, Prosvjetno društvo hrvatskih Zagoraca „Matija Gubec”, Zagreb, 1958., 139 - 143.

13. Ernest FIŠER, „Skica za portret Metela Ožegovića“, Godišnjak Gradske knjižnice $i$ čitaonice "Metel Ožegović" Varaždin, god. 1, br. 1, Gradska knjižnica i čitaonica "Metel Ožegović“", Varaždin, 1995., 107 - 111.

14. Vladimir GEIGER, et al., Partizanska i komunistička represija i zločini u Hrvatskoj 1944. - 1946.: dokumenti 3, Zagreb i Središnja Hrvatska, Hrvatski institut za povijest, Podružnica za povijest Slavonije, Srijema i Baranje, Hrvatski institut za povijest, Slavonski Brod - Zagreb, 2008.

15. Josip HABUNEK, Prehrana ljudi radovansko-bielskog kraja u prošlosti, Društvo prijatelja glazbe i narodnih običaja „Lompuš“ Radovan, Radovan, 2004.

16. Dubravko HOIĆ, Dubravka HOIĆ, „Gospodarska održivost projekta revitalizacije dvorca Bela II", Suvremeno korištenje i kreativno upravljanje dvorcima, kurijama i ljetnikovcima, zbornik radova Međunarodnog znanstveno-stručnog skupa održanog 10. studenoga 2005. godine u Zagrebu, urednik Nikša Božić, Arhitektonski fakultet Zagreb, Zagreb, 2005., 143 - 154.

17. Anđela HORVAT, Radmila MATEJČIĆ, Kruno PRIJATELJ, Barok u Hrvatskoj, Sveučilišna naklada Liber - Odjel za povijest umjetnosti Centra za povijesne znanosti - Društvo povjesničara umjetnosti Hrvatske - Grafički zavod Hrvatske - Kršćanska sadašnjost, Zagreb, 1982.

18. Rudolf HORVAT, „Ožegović Barlabaševački bar. Metel“, Znameniti i zaslužni Hrvati te pomena vrijedna lica u hrvatskoj povijesti od 925 - 1925, urednik Emilij LASZOWSKI, Odbor za izdanje knjige „Zaslužni i znameniti Hrvati 925 1925“, Zagreb, 1925.

19. Julije JANKOVIĆ, Pabirci po povjesti županije Varaždinske / pribrao ih Julije Janković, Brzotiskom Stjepana Platzera, Varaždin, 1898.

20. Ivančica JEŽ, „Neka obilježja preporodnog razdoblja nacionalnog pokreta u Varaždinu (1838. - 1848.)“, Historia Varasdiensis: časopis za varaždinsku povjesnicu, vol. 1, br. 1, Društvo povjesničara grada Varaždina i Varaždinske županije, Varaždin, 2011., 145 - 156.

21. Ivančica JEŽ, „Varaždinsko 'Družtvo narodno' - prva hrvatska narodna čitaonica (1838. - 1848.)“, Vjesnik bibliotekara Hrvatske, vol. 53, br. 1, Hrvatsko knjižničarsko društvo, Zagreb, 2010., 120 - 131. 
22. Lucija KONFIC, „Lucija Ožegović - život i karijera obilježeni ulogom majke“, Cris: časopis Povijesnog društva Križevci, XIV/1, Povijesno društvo Križevci, Križevci, 2012., 45 - 62.

23. Ankica KOŠĆAK, Katarina VUGREK, „Povijest školstva“, Škola Margečan: 1912. - 2012., uredile Ankica KOŠĆAK i Dubravka MIHINJAČ, TIVA Tiskara Varaždin - Osnovna škola Metel Ožegović Radovan, Varaždin, 2012.

24. Marijan KRAŠ, Ivanec: prilozi povijesti Ivanca do 1940. godine, Zlati ajngel, Varaždin, 1996.

25. Milan KRUHEK, Krajiške utvrde i obrana hrvatskog kraljevstva tijekom 16. stoljeća, Institut za suvremenu povijest, Zagreb, 1995.

26. Ivan KUKULJEVIĆ-SAKCINSKI, Natpisi sredovječni i novovjeki na crkvah, javnih i privatnih zgradah itd. u Hrvatskoj i Slavoniji sabrao Ivan Kukuljević-Sakcinski, Knjižara Jugoslavenske akademije, Knjižara Dioničke tiskare, Zagreb, 1891.

27. Karmen LEVANIĆ, prijevodi latinskih natpisa u: Krešimir Filić, Povijesni natpisi grada Varaždina, urednici Vladimir HUZJAN i Spomenka TEŽAK, biografske jedinice izradili Vladimir HUZJAN, Ana ŠKRILJEVEČKI i Spomenka TEŽAK, Hrvatska akademija znanosti i umjetnosti, Zavod za znanstveni rad u Varaždinu, Gradski muzej Varaždin, Zagreb - Varaždin, 2017.

28. Magdalena LONČARIĆ, Varaždinska dobrotvorna društva 1828. - 1945., katalog izložbe priređene povodom Dana grada Varaždina, Gradski muzej Varaždin, Varaždin, 2001.

29. Andrija LUKINOVIĆ, Župa Margečan, Župni ured Margečan, Margečan, 1998.

30. Mladen OBAD ŠĆITAROCI, Dvorci i perivoji Hrvatskoga zagorja, Školska knjiga, Zagreb, 1993.

31. Lucija OŽEGOVIĆ, Pismo mrtvom sinu, Zora, Zagreb, 1953.

32. Branko SVOBODA, Stare vinogradarske kurije i kleti, Kulturno-prosvjetno društvo hrvatskih Zagoraca „Matija Gubec“, Zagreb, 1967.

33. Agneza SZABO, ,,Metel Ožegović u političkom i kulturno-prosvjetnom životu Hrvatske“" Cris: časopis Povijesnog društva Križevci, XIV/1, Povijesno društvo Križevci, Križevci, 2012., 196 - 202.

34. Gjuro SZABO, Kroz Hrvatsko Zagorje, Izdanje knjižare Vasić (Vasić i Horvat), Zagreb, 1939.

35. Gjuro SZABO, Sredovječni gradovi u Hrvatskoj i Slavoniji, Matica hrvatska, Zagreb, 1920.

36. Eduard VARGOVIĆ, „Bibliografski izvori o Metelu Ožegoviću“, Radovi Zavoda za znanstveni rad Varaždin, broj 8 - 9, Hrvatska akademija znanosti i umjetnosti, Zavod za znanstveni rad Varaždin, Zagreb - Varaždin, 1996., 135 $-147$. 
37. Andrej ŽMEGAČ, „Prilog poznavanju dvorca Bela II.“, Kaj: časopis za književnost, umjetnost i kulturu, god. 40, br. 1 - 2, Kajkavsko spravišče - društvo za širenje i unapređivanje znanosti i umjetnosti, Zagreb, 2007., 65 - 75.

\section{Internetske stranice}

1. Ministarstvo kulture Republike Hrvatske, Registar kulturnih dobara Republike Hrvatske, URL: https://www.min-kulture.hr/default.aspx?id=6212 datum pristupa: 22. kolovoza 2018.

\section{SAŽETAK \\ OBITELJ OŽEGOVIĆ U BELI}

Posjed Bela obilježilo je svojim djelovanjem pet generacija obitelji Ožegović. Stjepan Ožegović započeo je kupovati dijelove imanja, što je nastavio njegov sin Metel. U vrijeme Metela Ožegovića, njegovog sina Ljudevita i unuka Ivana, kada je Bela bila na vrhuncu razvoja, prostrano se imanje sastojalo od utvrde Pusta Bela, starijeg dvorca Bela I okruženog perivojem, mlađeg dvorca Bela II s uređenim vrtovima, obiteljske grobnice u kapelici Majke Božje te obrađivanih poljoprivrednih, vinogradarskih i šumarskih površina. Obitelj je Ožegović obnovila posjed te ga učinila kulturno i gospodarski razvijenim vlastelinstvom. Doprinijeli su napretku života lokalnog stanovništva osnivanjem pučke škole i pokroviteljstvom nad Župom Margečan. Tragično stradanje Metela i Emilije Ožegović te parcelacija belskoga posjeda nakon Drugoga svjetskog rata izazvali su njegovo postupno propadanje čije se posljedice očituju do današnjih dana.

Ključne riječi: obitelj Ožegović; Metel Ožegović; vlastelinstvo Bela; Pusta Bela; Bela I; Bela II; Župa Margečan; Osnovna škola Metel Ožegović Radovan; masovna grobnica Tužno. 


\section{SUMMARY \\ FAMILY OŽEGOVIĆ IN BELA}

For five generations the Bela estate was part of the family Ožegović who each left their mark on the property. Stephen Ožegović began purchasing the estate and his son Metel continued with the process. During the rule of Metel Ožegović, his son Louis and grandson John, the Bela estate was at the height of its development. The prosperous estate consisted of the burg of Bela, older castle called Bela I, younger castle called Bela II, both surrounded by gardens, farmlands, vineyards and forests. Also found on the estate was the family crypt that was situated in the Chapel of Our Lady. The family renewed the property culturally and economically. They contributed to the progress of the local community by establishing a public school and by being patrons of the Margečan parish. The tragic deaths of Metel and Emilia Ožegović together with land division of the estate after the World War II led to its gradual decay. The consequences of those actions can be seen to this day.

Key Words: family Ožegović; Metel Ožegović; Bela estate; burg of Bela; Bela I; Bela II; Margečan parish; primary school Metel Ožegović Radovan; mass grave Tužno. 